\title{
Mechanism underlying the efficacy of combination therapy with losartan and hydrochlorothiazide in rats with salt-sensitive hypertension
}

\author{
Yuichiro Yamada ${ }^{1}$, Koji Tsuboi ${ }^{2}$, Takuya Hattori ${ }^{2}$, Tamayo Murase ${ }^{2}$, Masafumi Ohtake ${ }^{2}$, Mayuko Furukawa ${ }^{2}$,
} Jun Ueyama ${ }^{1}$, Akira Nishiyama ${ }^{3}$, Toyoaki Murohara ${ }^{4}$ and Kohzo Nagata ${ }^{1}$

\begin{abstract}
Although thiazide diuretics are commonly used to supplement angiotensin receptor blockers for treatment of hypertension, the mechanism underlying the therapeutic effects of this drug combination remains unclear. We investigated the antihypertensive and cardioprotective effects of combination therapy with losartan (LOS) and hydrochlorothiazide (HCTZ), in comparison with those of either drug alone, in Dahl salt-sensitive hypertensive rats. Rats fed a high-salt diet from 6 weeks of age were treated with LOS, HCTZ, both drugs (COMB) and vehicle from 6 to 11 weeks. The salt-induced increase in systolic blood pressure was attenuated moderately by LOS and to a greater extent by HCTZ and COMB. Left ventricular (LV) hypertrophy and fibrosis, diastolic dysfunction, as well as angiotensin-converting enzyme and angiotensin II type $1 \mathrm{~A}\left(\mathrm{AT}_{1 \mathrm{~A}}\right)$ receptor gene expression were attenuated similarly by LOS and HCTZ and more so by COMB. LOS downregulated expression of the AT ${ }_{1 A}$ receptor gene, without affecting that of the $\mathrm{AT}_{2}$ receptor gene, in the aorta. In contrast, neither HCTZ nor COMB affected aortic expression of the $\mathrm{AT}_{1 \mathrm{~A}}$ receptor gene, but both markedly upregulated that of the $\mathrm{AT}_{2}$ receptor gene. The salt-induced decrease in the plasma concentration of nitric oxide metabolites was attenuated substantially by LOS and abolished by both HCTZ and COMB. In conclusion, the combination of LOS and HCTZ attenuated hypertension, as well as LV remodeling and diastolic dysfunction, more effectively than did LOS or HCTZ alone in rats with salt-sensitive hypertension. Modulation of the cardiac and vascular renin-angiotensin system may have contributed to these beneficial effects of the drug combination.

Hypertension Research (2011) 34, 809-816; doi:10.1038/hr.2011.34; published online 7 April 2011
\end{abstract}

Keywords: angiotensin; diuretic; sodium

\section{INTRODUCTION}

Hypertension is the most prevalent modifiable risk factor for cardiovascular disease and the most common risk factor for death from any

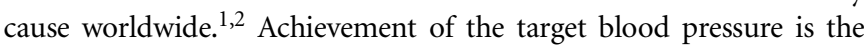
key objective of antihypertensive treatment. Angiotensin receptor blockers (ARBs) exert an antihypertensive effect by specifically inhibiting the binding of angiotensin II to the angiotensin II type $1\left(\mathrm{AT}_{1}\right)$ receptor. ${ }^{3}$ Losartan (LOS) was the first member of this class of cardiovascular drugs available for the treatment of hypertension and also holds potential for that of cardiovascular disease. ${ }^{4}$ Clinical trials have shown that administration of LOS alone lowers blood pressure, and is well tolerated in individuals with hypertension. ${ }^{5-8}$ Furthermore, LOS was found to have beneficial effects on renal and cardiovascular outcomes independent of its antihypertensive function. , $^{9,10}$

Thiazide diuretics such as hydrochlorothiazide (HCTZ) have also been used for the treatment of hypertension and affect renal tubular mechanisms of electrolyte reabsorption, directly increasing the excretion of $\mathrm{Na}^{+}$and $\mathrm{Cl}^{-}$. However, the mechanism underlying the long-term antihypertensive effect of HCTZ is not fully understood. Given that thiazide diuretics reduce morbidity and mortality in hypertensive patients, ${ }^{11,12}$ the Seventh Report of the Joint National Committee recommends these agents for use as first-line drugs in the treatment of hypertension. ${ }^{13}$ The Japanese Society of Hypertension Guidelines for the Management of Hypertension also recommend diuretics in low doses as first-line drugs for the treatment of hypertension. ${ }^{14}$ Moreover, it is possible that regimens including putatively safer, non-loop diuretics such as thiazide drugs would prove effective for maintenance of euvolemia in salt-sensitive and salt-avid individuals. $^{15}$

For patients who do not respond to monotherapy, combinations of two or more antihypertensive drugs are recommended. ${ }^{14}$ Combination therapy with an ARB and a thiazide diuretic is highly efficacious

\footnotetext{
${ }^{1}$ Department of Medical Technology, Nagoya University School of Health Sciences, Nagoya, Japan; ${ }^{2}$ Department of Pathophysiological Laboratory Sciences, Nagoya University Graduate School of Medicine, Nagoya, Japan; ${ }^{3}$ Department of Pharmacology, Faculty of Medicine, Kagawa University, Kagawa, Japan and ${ }^{4}$ Department of Cardiology, Nagoya University Graduate School of Medicine, Nagoya, Japan

Correspondence: Professor K Nagata, Department of Medical Technology, Nagoya University School of Health Sciences, 1-1-20 Daikominami, Higashi-ku, Nagoya 461-8673, Japan.

E-mail: nagata@met.nagoya-u.ac.jp

This research has been accepted for presentation at the 23rd Scientific Meeting of the International Society of Hypertension (ISH 2010 ), Vancouver, 26-30 September 2010. Received 10 August 2010; revised 15 January 2011; accepted 31 January 2011; published online 7 April 2011
} 
for the treatment of hypertension. ${ }^{16}$ However, the mechanism underlying the antihypertensive and cardioprotective effects of this combination remains to be elucidated. We have now investigated the effects of the combination of LOS and HCTZ on blood pressure, cardiac remodeling and cardiac and aortic gene expression, in comparison with those of each drug alone, in rats with salt-sensitive hypertension.

\section{METHODS}

\section{Animals and experimental protocols}

Male inbred Dahl salt-sensitive (DS) rats were obtained from Japan SLC (Hamamatsu, Japan) and were handled in accordance with the guidelines of Nagoya University Graduate School of Medicine. Weaning rats were fed laboratory chow containing $0.3 \% \mathrm{NaCl}$ until 6 weeks of age. DS rats fed an $8 \% \mathrm{NaCl}$ diet after 6 weeks of age were treated with LOS $(30 \mathrm{mg}$ per kilogram of body weight; Merck, Rahway, NJ, USA) once daily by gavage, HCTZ (75 $\mathrm{mgl}^{-1}$; Merck) in drinking water, the combination of LOS and HCTZ ( $\mathrm{L}+\mathrm{H}$ group) at the same doses as those administered as monotherapy, or vehicle (LVH group) from 7 weeks of age. The doses of LOS and HCTZ were determined from the results of a previous study. ${ }^{17,18}$ The vehicle group progressively developed pronounced hypertension and manifested hypertension-induced compensated left ventricular hypertrophy (LVH) at 11 weeks. DS rats maintained on a $0.3 \% \mathrm{NaCl}$ diet after 6 weeks of age remain normotensive, and such animals served as age-matched controls (CONT group). The treatment and control groups each comprized six animals. At 11 weeks of age, all rats were anesthetized by intraperitoneal injection of ketamine $\left(50 \mathrm{mg} \mathrm{kg}^{-1}\right)$ and xylazine $\left(10 \mathrm{mg} \mathrm{kg}^{-1}\right)$ and were subjected to echocardiographic and hemodynamic analyses. The animals were then deprived of food overnight for collection of a blood sample, after which the heart was excised and left ventricular (LV) tissue was separated for analysis.

\section{Echocardiographic and hemodynamic analyses}

Systolic blood pressure (SBP) was measured weekly in conscious animals by tail-cuff plethysmography (BP-98A; Softron, Tokyo, Japan). At 11 weeks of age, rats were subjected to transthoracic echocardiography as previously described. ${ }^{19}$ In brief, M-mode echocardiography was carried out with the use of an Aplio SSA-700A system equipped with a $12.5-\mathrm{MHz}$ transducer (Toshiba, Tochigi, Japan). LV end-diastolic (LVDd) and end-systolic (LVDs) dimensions, as well as the thickness of the LV posterior wall (LVPWT) were measured, and LV fractional shortening (LVFS) was calculated as follows: LVFS (\%)= $(($ LVDd-LVDs)/LVDd $) \times 100$. After echocardiography, a $2 \mathrm{~F}$ micromanometertipped catheter (SPR-407; Millar Instruments, Houston, TX, USA) that had been calibrated relative to atmospheric pressure was inserted through the right carotid artery into the LV. ${ }^{20}$ Tracings of LV pressure and the electrocardiogram were digitized to determine LV end-diastolic pressure (LVEDP). The time constant of isovolumic relaxation (tau) was calculated by the derivative method of Raff and Glantz, as described previously. ${ }^{21}$

\section{Histology}

$\mathrm{LV}$ tissue was fixed with ice-cold $4 \%$ paraformaldehyde for $48-72 \mathrm{~h}$, embedded in paraffin wax and processed for histology as described. ${ }^{22}$ In brief, transverse sections (thickness, $3 \mu \mathrm{m}$ ) were stained either with hematoxylin-eosin for routine histological examination or with Azan-Mallory solution for evaluation of the extent of fibrosis. All image analysis was carried out with NIH Scion Image software (Scion Corp., Frederick, MD, USA).

\section{Quantitative RT-PCR analysis}

Total RNA was extracted from LV or aortic tissue and treated with deoxyribonuclease with the use of a spin-vacuum total RNA isolation kit (Promega, Madison, WI, USA). Portions of the RNA $(2 \mu \mathrm{g})$ were subjected to reverse transcription (RT) with the use of random primers (Invitrogen, Carlsbad, CA, USA) and MuLV Reverse Transcriptase (Applied Biosystems, Foster City, CA, USA). The resulting complementary DNA was subjected to real-time PCR analysis with the use of a Prism 7700 Sequence Detector (Perkin-Elmer, Waltham, MA, USA), as previously described, ${ }^{23}$ and with primers and TaqMan probes specific for atrial natriuretic peptide (ANP), ${ }^{22}$ brain natriuretic peptide (BNP), ${ }^{22}$ collagen type $\mathrm{I}^{24}$ or type $\mathrm{III},{ }^{24}$ angiotensin-converting enzyme (ACE), ${ }^{22}$ the $\mathrm{AT}_{1 \mathrm{~A}}{ }^{22}$ or $\mathrm{AT}_{2}$ (5'-CTGGCTGTGGCTGACTTACTC-3', $5^{\prime}$-TTTGC ACATCACAGGTCCAAAG- ${ }^{\prime}$, and $5^{\prime}$-TTGGCAACCCTTCCTCTCTGGGCA- ${ }^{\prime}$ as the forward primer, reverse primer and TaqMan probe, respectively; GenBank accession no. NM_022456) receptor, transforming growth factor$\beta 1$ (TGF- $\beta 1)^{22}$ or connective tissue growth factor (CTGF). ${ }^{25}$ Reagents for detection of human $18 \mathrm{~S}$ rRNA (Applied Biosystems) were used to quantify rat $18 \mathrm{~S}$ rRNA as an internal standard.

\section{Plasma analysis}

A blood sample was collected from the right carotid artery of rats after overnight deprivation of food. Plasma renin activity was determined by radioimmunoassay with the use of renin RIA beads (Abbott Japan, Tokyo, Japan). Plasma angiotensin II concentration was determined by radioimmunoassay as described previously. ${ }^{26,27}$ Plasma aldosterone concentration was measured by radioimmunoassay with the use of a DPC aldosterone kit (Mitsubishi Chemical Medience, Tokyo, Japan). The plasma concentration of nitric oxide metabolites $\left(\mathrm{NO}_{x}\right)$ was determined by the Griess method with the use of a Nitrate/Nitrite Colorimetric Assay Kit (Cayman Chemical, Ann Arbor, MI, USA), as previously described. ${ }^{28}$

\section{Statistical analysis}

Data are presented as means \pm s.e.m. Differences among groups of rats at 11 weeks of age were assessed by one-way factorial analysis of variance; if a significant difference was detected, intergroup comparisons were performed with Fisher's multiple-comparison test. The time course of SBP was compared among groups by two-way repeated-measures analysis of variance. A $P$ value of $<0.05$ was considered statistically significant.

\section{RESULTS}

\section{LV geometry and function}

SBP was significantly higher in the LVH group than in the CONT group at 7 weeks of age and thereafter (Figure 1 and Table 1). SBP was significantly lower in the LOS, HCTZ, and $\mathrm{L}+\mathrm{H}$ groups than in the LVH group at 8 weeks of age and thereafter. Although the HCTZ and $\mathrm{L}+\mathrm{H}$ groups showed a significant decrease in SBP from 8 to 11 weeks compared with the LOS group, there was no significant difference in SBP between the HCTZ and $\mathrm{L}+\mathrm{H}$ groups from 6 to 11 weeks. Body weight and heart rate were similar among all five groups of rats at

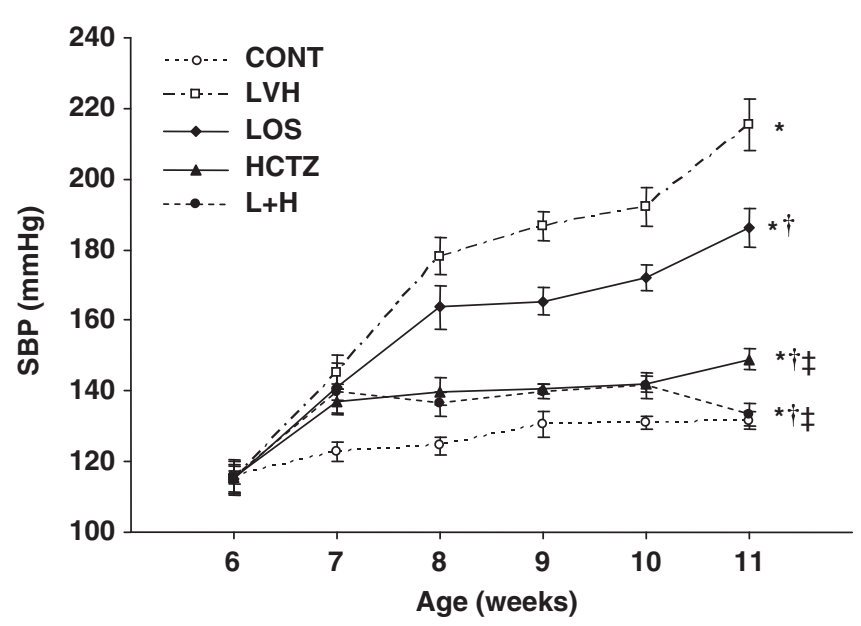

Figure 1 Time course of systolic blood pressure (SBP) in Dahl salt-sensitive (DS) rats of the five experimental groups. Data are means \pm s.e.m. ( $n=6$ rats per group). ${ }^{*} P<0.05$ vs. CONT; ${ }^{\dagger} P<0.05$ vs. left ventricular hypertrophy (LVH); ${ }^{\ddagger} P<0.05$ vs. losartan (LOS). 
11 weeks of age (Table 1). The ratio of LV weight to tibial length, an index of LVH, was significantly increased in the LVH group compared with the CONT group. The development of salt-induced LVH was suppressed to a greater extent by the combination of LOS and HCTZ than by LOS or HCTZ alone (Table 1).

Echocardiography revealed that LVDd was decreased and both LVPWT and LVFS were increased in the LVH group compared with the CONT group (Table 2). The decrease in LVDd was attenuated by all treatments, and the increase in LVPWT was attenuated similarly by each monotherapy and to a greater extent by the combination therapy. The increase in LVFS was prevented by all drug treatments. Both the isovolumic relaxation time and tau, indexes of LV relaxation, as well as LVEDP were significantly increased in the LVH group compared with the CONT group (Table 2). The ratio of LVEDP to LVDd, an index of LV diastolic stiffness, was also increased in the LVH group. All of these changes were similarly attenuated by each monotherapy and were normalized by the combination therapy.

\section{Cardiomyocyte hypertrophy, cardiac fibrosis and cardiac gene expression}

Microscopic analysis revealed that the cross-sectional area of LV cardiomyocytes was increased in the LVH group compared with the CONT group (Figures $2 \mathrm{a}$ and $\mathrm{b}$ ). The overload-induced increase in this parameter was significantly attenuated by treatment with LOS or HCTZ alone and normalized by the combination of both drugs. Hemodynamic overload also resulted in marked upregulation of ANP and BNP gene expression in the LV (Figures $2 \mathrm{c}$ and $\mathrm{d}$ ). The expression of these fetal-type cardiac genes was inhibited markedly by each monotherapy and even more so by combination therapy.

Azan-Mallory staining revealed that fibrosis in perivascular and interstitial regions of the LV myocardium was increased in the $\mathrm{LVH}$ group as compared with that apparent in the CONT group

Table 1 Physiological and morphological parameters of DS rats in the five experimental groups at 11 weeks of age

\begin{tabular}{|c|c|c|c|c|c|}
\hline Parameter & CONT & $L V H$ & LOS & HCTZ & $L+H$ \\
\hline Body weight (g) & $338 \pm 7$ & $342 \pm 6$ & $337 \pm 12$ & $341 \pm 1$ & $322 \pm 11$ \\
\hline $\mathrm{SBP}(\mathrm{mm} \mathrm{Hg})$ & $132 \pm 3$ & $215 \pm 7^{*}$ & $186 \pm 5^{*, \dagger}$ & $149 \pm 3^{*, \dagger, \ddagger}$ & $133 \pm 3^{\dagger, \ddagger}$ \\
\hline HR (b.p.m.) & $392 \pm 6$ & $402 \pm 8$ & $398 \pm 11$ & $405 \pm 8$ & $409 \pm 11$ \\
\hline $\mathrm{LVW} / \mathrm{TL}\left(\mathrm{mg} \mathrm{mm}^{-1}\right)$ & $19.9 \pm 0.6$ & $30.3 \pm 1.2^{*}$ & $25.3 \pm 1.1^{*, \dagger}$ & $23.0 \pm 0.6^{*, \dagger}$ & $20.4 \pm 0.3^{\dagger, \ddagger, \S}$ \\
\hline
\end{tabular}

Abbreviations: HCTZ, hydrochlorothiazide; HR, heart rate; LOS, losartan; LVH, left ventricular hypertrophy; LVW, left ventricular weight; L+H, combination of LOS and HCTZ; SBP, systolic blood pressure; $\mathrm{TL}$, tibial length.

Data are means \pm s.e.m. ( $n=6$ rats per group). ${ }^{*} P<0.05$ vs. CONT group; ${ }^{\dagger} P<0.05$ vs. LVH group; ${ }^{\ddagger} P<0.05$ vs. LOS group; ${ }^{\circledR} P<0.05$ vs. HCTZ group.
(Figures 3a-c). These increases in the extent of LV fibrosis were significantly attenuated by each monotherapy and normalized by combination therapy. The amounts of collagen type I and type III mRNAs were also increased in the LV of rats in the LVH group (Figures $3 \mathrm{~d}$ and e). The abundance of these transcripts was reduced greatly by each monotherapy and even more so by combination therapy.

\section{Plasma renin activity, as well as angiotensin II and aldosterone} levels

Salt loading reduced renin activity, as well as the angiotensin II and aldosterone concentrations in plasma of DS rats, and these changes were not affected by any of the three drug treatments (Figure 4).

Cardiac TGF- $\beta 1, \mathrm{CTGF}, \mathrm{ACE}$ and $\mathrm{AT}_{1 \mathrm{~A}}$ receptor gene expression The amounts of mRNAs for the profibrotic factors TGF- $\beta 1$ and CTGF in the LV were significantly increased in the LVH group compared with the CONT group (Figures $5 \mathrm{a}$ and $\mathrm{b}$ ). The abundance of these mRNAs was reduced markedly by treatment with LOS or HCTZ alone and to a greater extent by both drugs. Expression of the ACE gene was significantly upregulated in the LV of rats in the LVH group compared with the CONT group, whereas $\mathrm{AT}_{1 \mathrm{~A}}$ receptor gene expression was not changed (Figures $5 \mathrm{c}$ and $\mathrm{d}$ ). The salt-induced increase in ACE gene expression was prevented by LOS or HCTZ alone, and the amount of ACE mRNA was reduced to levels below those in the CONT group by the drug combination. Expression of the $\mathrm{AT}_{1 \mathrm{~A}}$ receptor gene was significantly downregulated by LOS or HCTZ alone and was reduced to an even greater extent by combination therapy. The $\mathrm{AT}_{2}$ receptor gene was expressed at only minimal levels in the heart of animals in all groups (data not shown).

Aortic $\mathrm{ACE}, \mathrm{AT}_{1 \mathrm{~A}}$ receptor and $\mathrm{AT}_{2}$ receptor gene expression and plasma $\mathrm{NO}_{x}$ concentration

Hemodynamic overload resulted in upregulation of ACE gene expression in the aorta in a manner similarly sensitive to each of the three treatments (Figure 6a). Pressure overload did not affect the amounts of $\mathrm{AT}_{1 \mathrm{~A}}$ or $\mathrm{AT}_{2}$ receptor mRNAs in the aorta (Figures $6 \mathrm{~b}$ and $\mathrm{c}$ ). Treatment with LOS reduced the aortic abundance of $\mathrm{AT}_{1 \mathrm{~A}}$ receptor mRNA without affecting that of $\mathrm{AT}_{2}$ receptor mRNA, whereas both HCTZ and combination therapy did not affect the amount of $\mathrm{AT}_{1 \mathrm{~A}}$ receptor mRNA but induced a 5.4-fold increase in $\mathrm{AT}_{2}$ gene expression compared with that in the LVH group. Finally, the plasma $\mathrm{NO}_{x}$ concentration was significantly lower in the LVH group than in the CONT group, and this difference was significantly attenuated by LOS alone and was abolished by both HCTZ and combination therapy (Figure 6d).

Table 2 Cardiac functional parameters of DS rats in the five experimental groups at 11 weeks of age

\begin{tabular}{|c|c|c|c|c|c|}
\hline Parameter & CONT & $L V H$ & LOS & HCTZ & $L+H$ \\
\hline LVDd (mm) & $8.35 \pm 0.19$ & $7.45 \pm 0.13^{*}$ & $8.04 \pm 0.11 \dagger$ & $8.23 \pm 0.17^{\dagger}$ & $8.28 \pm 0.07^{\dagger}$ \\
\hline LVPWT (mm) & $1.54 \pm 0.02$ & $2.36 \pm 0.07 *$ & $1.77 \pm 0.03^{*, \dagger}$ & $1.74 \pm 0.02 *, \dagger$ & $1.60 \pm 0.04^{\dagger, \ddagger, \S}$ \\
\hline LVFS (\%) & $36.5 \pm 3.4$ & $44.5 \pm 1.5^{*}$ & $36.4 \pm 2.2^{\dagger}$ & $34.1 \pm 1.6^{\dagger}$ & $36.5 \pm 3.7^{\dagger}$ \\
\hline IRT (ms) & $18.7 \pm 2.2$ & $36.5 \pm 4.2^{*}$ & $28.1 \pm 2.6^{*, \dagger}$ & $26.6 \pm 1.0 *, \dagger$ & $20.1 \pm 1.3^{\dagger, \dagger, \ddagger, \S}$ \\
\hline Tau (ms) & $17.7 \pm 0.9$ & $49.2 \pm 7.7^{*}$ & $28.6 \pm 1.8^{*, \dagger}$ & $26.2 \pm 0.8^{*, \dagger}$ & $17.2 \pm 0.3^{\dagger, \ddagger, \S}$ \\
\hline LVEDP (mm Hg) & $4.3 \pm 0.3$ & $7.8 \pm 0.5^{*}$ & $5.8 \pm 0.1^{*, \dagger}$ & $6.0 \pm 0.1^{*, \dagger}$ & $4.8 \pm 0.1^{\dagger, \ddagger, \S}$ \\
\hline LVEDP/LVDd $\left(\mathrm{mm} \mathrm{Hg} \mathrm{mm}^{-1}\right)$ & $0.57 \pm 0.04$ & $1.05 \pm 0.07 *$ & $0.72 \pm 0.01^{*, \dagger}$ & $0.73 \pm 0.01^{*, \dagger}$ & $0.58 \pm 0.01^{\dagger, \ddagger, \S}$ \\
\hline
\end{tabular}

Abbreviations: HCTZ, hydrochlorothiazide; IRT, isovolumic relaxation time; LOS, losartan; LVDd, left ventricular end-diastolic; LVEDP, left ventricular end-diastolic pressure; LVFS, left ventricular fractional shortening; LVH, left ventricular hypertrophy; LVPWT, left ventricular posterior wall; L+H, combination of LOS and HCTZ.

Data are means \pm s.e.m. ( $n=6$ rats per group). ${ }^{*} P<0.05$ versus CONT group; ${ }^{P} P<0.05$ vs. LVH group; ${ }^{\ddagger} P<0.05$ vs. LOS group; ${ }^{\$} P<0.05$ vs. HCTZ group. 
a

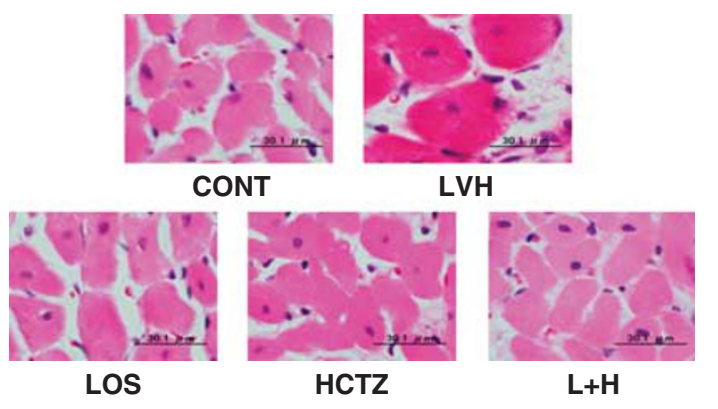

C

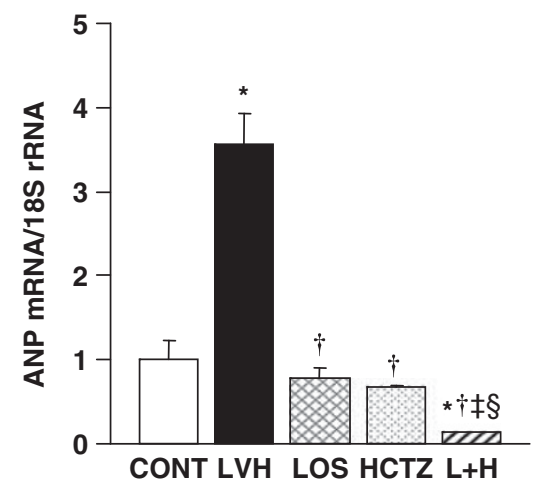

b

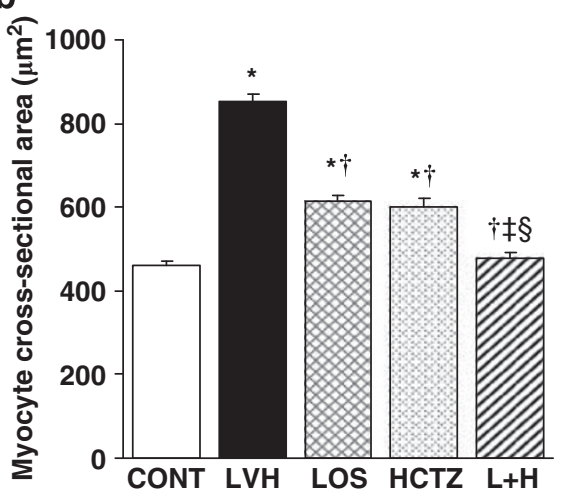

d

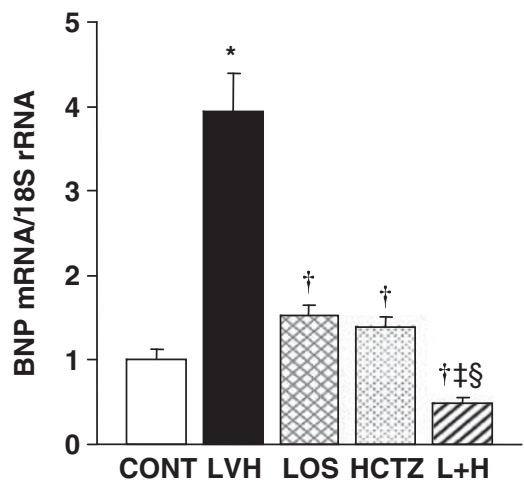

Figure 2 Cardiomyocyte size and expression of fetal-type cardiac genes in the left ventricle (LV) of Dahl salt-sensitive (DS) rats in the five experimental groups at 11 weeks of age. (a) Hematoxylin-eosin staining of transverse sections of the LV myocardium. Scale bars, $30.1 \mu \mathrm{m}$. (b) Cross-sectional area of cardiac myocytes determined from sections similar to those in (a). (c, d) Quantitative reverse-transcription (RT)-PCR analysis of atrial natriuretic peptide (ANP) and brain natriuretic peptide (BNP) mRNAs, respectively. The amount of each mRNA was normalized by that of $18 \mathrm{~S}$ rRNA and then expressed relative to the mean value for the CONT group. Data in (b) through (d) are means \pm s.e.m. ( $n=6$ rats per group). ${ }^{*} P<0.05$ vs. CONT; ${ }^{\dagger} P<0.05$ vs. left ventricular hypertrophy (LVH); ${ }^{\ddagger} P<0.05$ vs. losartan (LOS); ${ }^{\S} P<0.05$ vs. hydrochlorothiazide (HCTZ).

\section{DISCUSSION}

We have shown that combination therapy with LOS and HCTZ markedly attenuated LV remodeling and diastolic dysfunction, as well as lowered blood pressure in DS hypertensive rats. The antihypertensive and cardioprotective effects of this combination treatment are likely attributable not only to blockade of $\mathrm{AT}_{1}$ receptors and volume reduction, but also to modulation of the cardiac and vascular renin-angiotensin system (RAS).

ARBs such as LOS displace angiotensin II from its specific $\mathrm{AT}_{1}$ receptor, antagonizing all of the known effects of this hormone and resulting in a dose-dependent decrease in peripheral resistance, with little change in heart rate or cardiac output. ${ }^{29}$ In contrast, thiazide diuretics induce an acute reduction in cardiac output by reducing the volume of extracellular fluid and plasma, but the volume of extracellular fluid returns toward the original value during chronic use of these drugs and vasodilation supervenes. ${ }^{30}$ At steady state, therefore, the predominant effect of thiazides is vasodilation rather than volume contraction. Our present results show that HCTZ monotherapy induced a greater antihypertensive effect than did LOS monotherapy in DS rats and that combination therapy with both drugs also elicited a greater reduction in blood pressure compared with LOS alone, consistent with previous observations. ${ }^{31}$ However, the combination therapy did not result in a decrease in blood pressure greater than that induced by HCTZ monotherapy. One possible explanation for this lack of an additional hypotensive effect is that the dose of HCTZ administered resulted in a near maximal reduction in blood pressure in DS rats, so that the addition of LOS had no further effect. Another possibility is that this dose of HCTZ did not activate the systemic renin-angiotensin-aldosterone system (RAAS) in the presence of severe salt loading. ${ }^{31}$ Loop diuretics such as furosemide, at excessive doses, induce a contraction of intravascular volume, the hemodynamic signal for RAAS activation, as well as a reduction in the production of compensatory natriuretic peptides. Low doses of thiazide diuretics such as HCTZ have been effectively and safely used for the treatment of hypertension.

In this study, salt loading resulted in the upregulation of ACE gene expression, but not that of $\mathrm{AT}_{1 \mathrm{~A}}$ or $\mathrm{AT}_{2}$ receptor gene expression, in the aorta of DS rats. This increase in ACE gene expression was attenuated equally by all three drug treatments. In contrast, aortic expression of the $\mathrm{AT}_{1 \mathrm{~A}}$ receptor gene was downregulated by treatment with LOS alone but not by that with HCTZ either alone or in combination with LOS. Furthermore, aortic expression of the $\mathrm{AT}_{2}$ receptor gene was not affected by LOS monotherapy but was markedly increased by HCTZ either alone or in combination with LOS. Expression of $\mathrm{AT}_{2}$ receptors has previously been demonstrated in blood vessels, heart and kidney. ${ }^{32}$ ARBs have also been shown to increase the plasma concentration of angiotensin II by inhibiting the $\mathrm{AT}_{1}$ receptor-mediated negative feedback on renin release ${ }^{33}$ Blockade of $\mathrm{AT}_{1}$ receptors by $\mathrm{ARBs}$ can therefore result in stimulation of $\mathrm{AT}_{2}$ receptors in vessels, leading to activation of the bradykinin-nitric oxide (NO) pathway. In this study, however, the systemic RAAS remained markedly inhibited in animals subjected to any of 
a
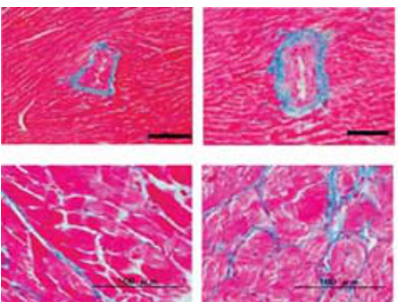

LVH

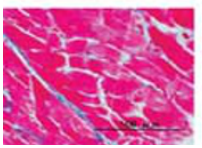

CONT$$
\text { LVH }
$$

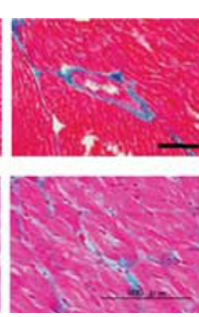

LOS

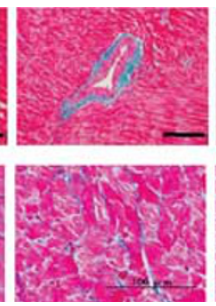

HCTZ

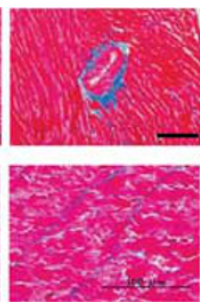

$\mathrm{L}+\mathrm{H}$
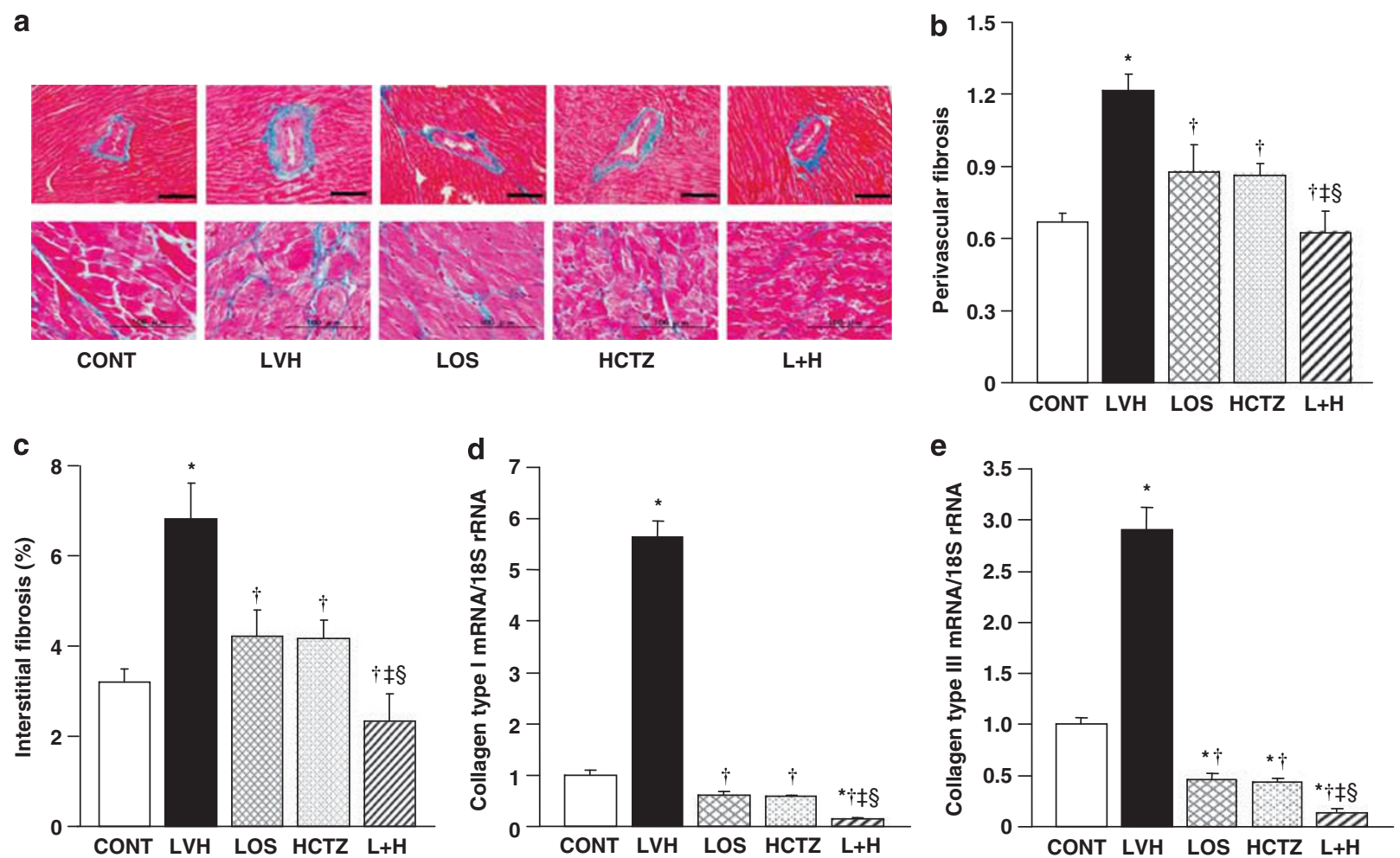

Figure 3 Cardiac fibrosis in the left ventricle (LV) of Dahl salt-sensitive (DS) rats in the five experimental groups at 11 weeks of age. (a) Collagen deposition as revealed by Azan-Mallory staining in perivascular (upper panels) or interstitial (lower panels) regions of the myocardium. Scale bars, $100 \mu \mathrm{m}$. (b, c) Relative extents of perivascular and interstitial fibrosis, respectively, in the LV myocardium as determined from sections similar to those in (a). (d, e) Quantitative reverse-transcription (RT)-PCR analysis of collagen type I and type III mRNAs, respectively. The amount of each mRNA was normalized by that of $18 \mathrm{~S}$ rRNA and then expressed relative to the mean value for the CONT group. Data in (b) through (e) are means \pm s.e.m. ( $n=6$ rats per group). ${ }^{*} P<0.05$ versus CONT; ${ }^{\dagger} P<0.05$ versus left ventricular hypertrophy (LVH); ${ }^{\ddagger} P<0.05$ vs. losartan (LOS); $\$ P<0.05$ vs. hydrochlorothiazide (HCTZ).
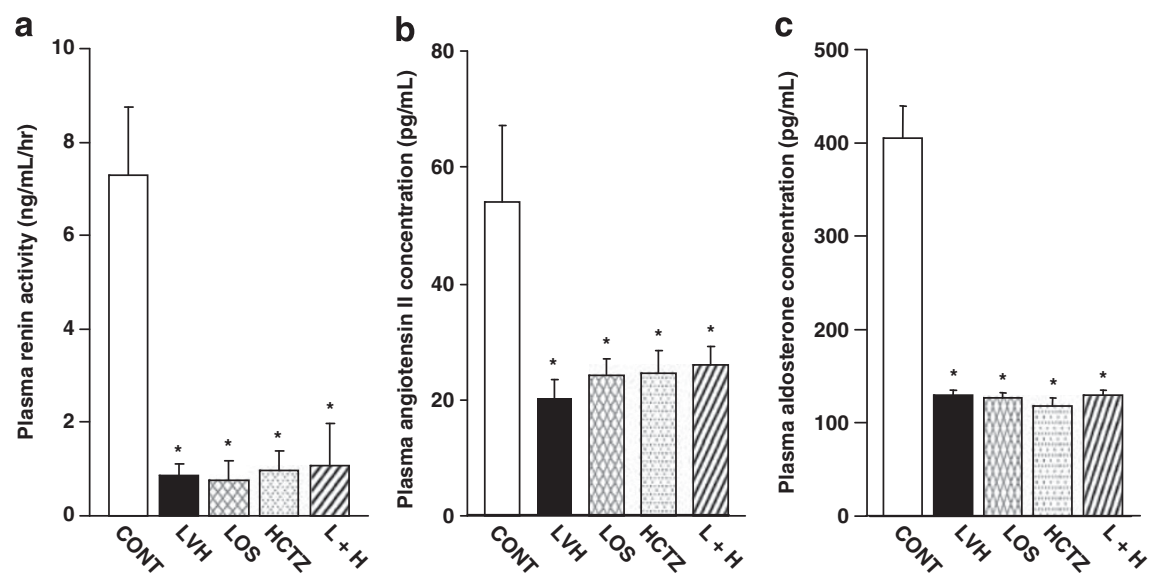

Figure 4 Plasma renin activity, as well as angiotensin II and aldosterone concentrations in Dahl salt-sensitive (DS) rats of the five experimental groups at 11 weeks of age. (a) Plasma renin activity. (b) Plasma angiotensin II concentration. (c) Plasma aldosterone concentration. All data are means \pm s.em. ( $n=6$ rats per group). ${ }^{*} P<0.05$ vs. CONT.

the three treatments, probably because of severe salt loading, whereas the plasma $\mathrm{NO}_{x}$ concentration was partially restored by LOS monotherapy and was normalized by HCTZ monotherapy or the combination therapy. It is thus possible that LOS-induced downregulation of $\mathrm{AT}_{1 \mathrm{~A}}$ receptor gene expression in the aorta may have contributed to the reduction in blood pressure induced by this drug. However, aortic $\mathrm{AT}_{2}$ receptors may not have participated in the antihypertensive effect of LOS monotherapy. In contrast, the marked upregulation of $\mathrm{AT}_{2}$ receptor gene expression in the aorta induced by HCTZ or by both drugs may have contributed to activation of the $\mathrm{AT}_{2}$ receptor-bradykinin-NO pathway, as reflected by the normalized plasma $\mathrm{NO}_{x}$ concentration.

Although it has been suggested that thiazide-induced vasodilation is mediated by the opening of $\mathrm{Ca}^{2+}$-activated $\mathrm{K}^{+}$channels or by 

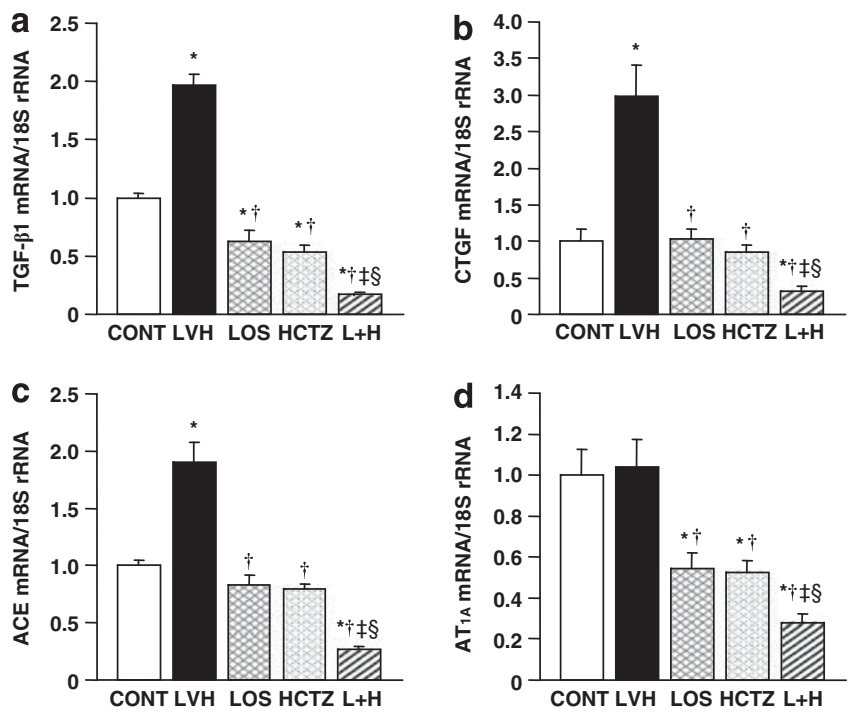

Figure 5 Expression of profibrotic and renin-angiotensin system (RAS) genes in the left ventricle (LV) of Dahl salt-sensitive (DS) rats in the five experimental groups at 11 weeks of age. The abundance of mRNAs for TGF- $\beta 1$ (a), CTGF (b), ACE (c) and the $\mathrm{AT}_{1 \mathrm{~A}}$ receptor (d) was determined by quantitative reverse-transcription (RT)-PCR analysis. The amount of each mRNA was normalized by that of 18S rRNA and then expressed relative to the mean value for the CONT group. All data are means \pm s.e.m. ( $n=6$ rats per group). ${ }^{*} P<0.05$ vs. CONT; ${ }^{\dagger} P<0.05$ vs. left ventricular hypertrophy (LVH); ${ }^{\ddagger} P<0.05$ vs. losartan (LOS); ${ }^{\S} P<0.05$ vs. hydrochlorothiazide (HCTZ).
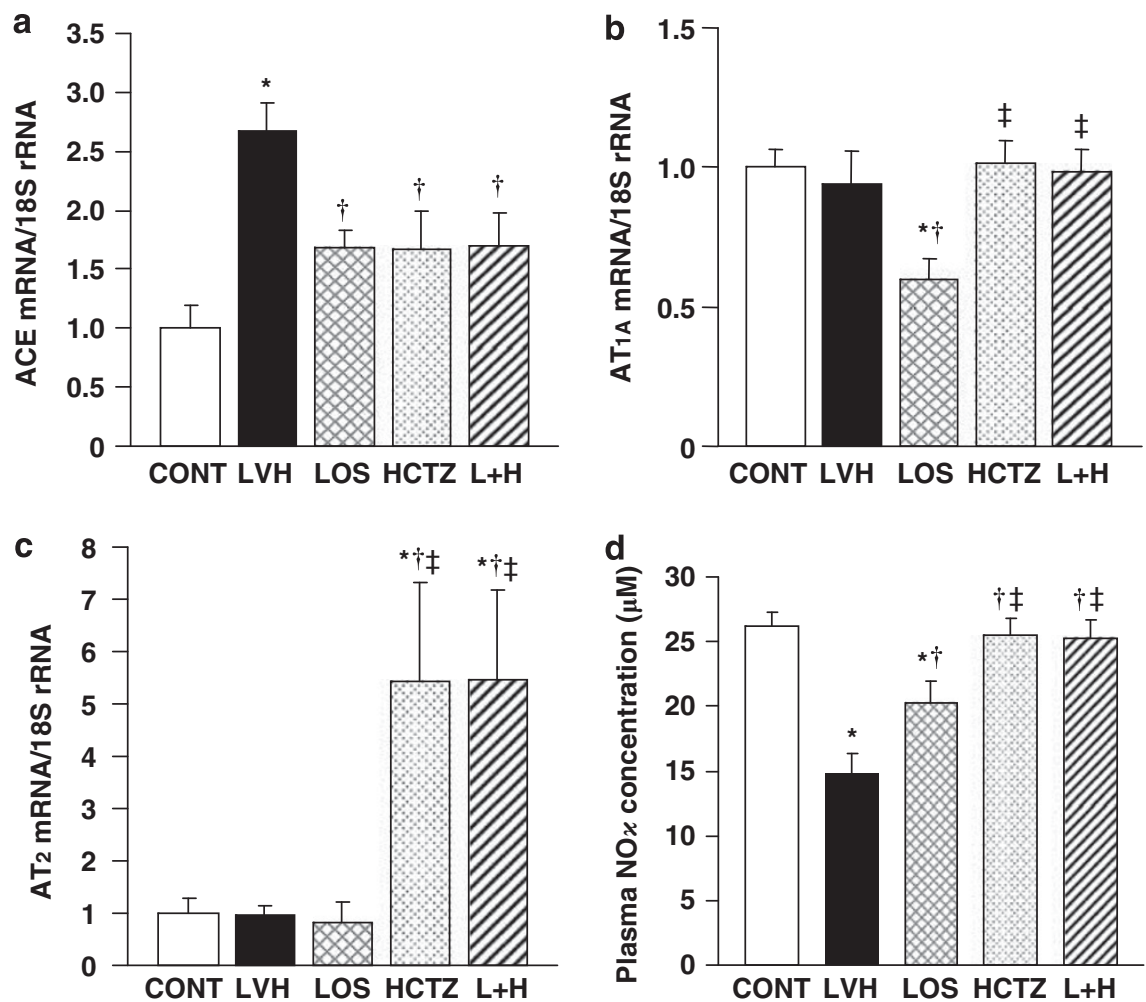

Figure 6 Expression of renin-angiotensin system (RAS) genes in the aorta and the plasma $\mathrm{NO}_{x}$ concentration in Dahl salt-sensitive (DS) rats of the five experimental groups at 11 weeks of age. $(\mathbf{a}-\mathbf{c})$ Quantitative reverse-transcription (RT)-PCR analysis of mRNAs for $A C E$ and the $A T_{1 A}$ and $A T_{2}$ receptors, respectively. The amount of each mRNA was normalized by that of $18 \mathrm{~S}$ rRNA and then expressed relative to the mean value for the CONT group. (d) Plasma $\mathrm{NO}_{x}$ concentration. All data are means \pm s.e.m. ( $n=6$ rats per group). ${ }^{*} P<0.05$ vs. CONT; ${ }^{\dagger} P<0.05$ vs. left ventricular hypertrophy (LVH); ${ }^{\ddagger} P<0.05$ vs. losartan (LOS). 
In this study, the systemic RAAS was suppressed by salt loading, whereas the cardiac RAS was activated, as shown by the upregulation of ACE gene expression apparent in the heart of rats in the LVH group, consistent with our previous results. ${ }^{22}$ This increase in cardiac ACE gene expression may have contributed to an increase in angiotensin II-mediated signaling in the heart. Expression of the $\mathrm{AT}_{1}$ receptor has been shown to be upregulated in several models of cardiac hypertrophy, ${ }^{39}$ although the functional relevance of this change was not clear. However, myocardial expression of the $\mathrm{AT}_{1 \mathrm{~A}}$ receptor gene was not altered in LVH rats, consistent with our previous results. ${ }^{22}$ LOS induced only a moderate antihypertensive effect in this study, but it strongly inhibited $\mathrm{ACE}$ and $\mathrm{AT}_{1 \mathrm{~A}}$ receptor gene expression in the heart, consistent with the cardioprotective effects of ARBs. In contrast, HCTZ suppressed cardiac ACE and $\mathrm{AT}_{1 \mathrm{~A}}$ receptor gene expression to the same extent as did LOS, but its antihypertensive effect was greater than that of LOS. In addition, the expression patterns of mRNAs for fibroproliferative cytokines TGF- $\beta 1$ and CTGF in the experimental groups were parallel to those of cardiac $\mathrm{ACE}$ and $\mathrm{AT}_{1 \mathrm{~A}}$ receptor genes but not plasma angiotensin II levels. The data to date show that in most tissues local RAS amplifies the functions of circulating angiotensin II with important implications for physiology and pathophysiology of cardiovascular diseases. ${ }^{40}$ These data suggest that locally produced angiotensin II was much more important in cardiac injury than circulating angiotensin II in this model of hypertension. ${ }^{41}$ Indeed, local RAS has been shown to have a more important role in target organ damage than systemic RAS in various experimental hypertensive models. ${ }^{42}$ We cannot conclude whether or not the cardioprotective effect of HCTZ was attributable solely to its lowering of blood pressure on the basis of our present data. However, it is noteworthy that blood pressure was decreased significantly 1 week after initiation of HCTZ treatment and remained so until the end of the study period. The addition of LOS to HCTZ did not decrease blood pressure further compared with HCTZ monotherapy, but the combination treatment induced a greater inhibition of cardiac $\mathrm{ACE}$ and $\mathrm{AT}_{1 \mathrm{~A}}$ receptor gene expression than did either monotherapy. These results are consistent with the fact that the combination of thiazide diuretics and RAS inhibitors has been used to lower blood pressure and limit target-organ damage. ${ }^{43,44}$

We acknowledge a limitation that the indirect tail-cuff method used to determine SBP is not adequate for ruling out the possibility that the results could be attributable to differences in blood pressure between the different treatment groups. ${ }^{45}$ We also acknowledge that the use of anesthetics ketamine and xylazine may have affected some of our results including measurements of the RAS, because those agents may stimulate sympathetic nervous system in the rats.

In conclusion, we have shown that the combination of LOS and HCTZ prevented cardiac hypertrophy and fibrosis, as well as markedly reduced blood pressure in rats with salt-sensitive hypertension. The HCTZ-induced upregulation of $\mathrm{AT}_{2}$ receptor gene expression in the aorta may have contributed to the lowering of blood pressure through activation of the bradykinin-NO pathway. Further attenuation of cardiac remodeling induced by the combination of LOS and HCTZ compared with that elicited by HCTZ monotherapy was likely attributable to the inhibitory effect of LOS on the cardiac RAS. Our results also suggest that combination therapy with an ARB and thiazide diuretic is an effective strategy for the management of saltsensitive hypertension.

\section{CONFLICT OF INTEREST}

The authors declare no conflict of interest.

\section{ACKNOWLEDGEMENTS}

We thank Masaaki Miyachi, Hiroki Yazawa, Chisa Inoue, Yukiko Ichikawa, Yuriko Ogawa, and Natsumi Misaki for technical assistance. Source of Funding: This work was supported in part by research grants from MSD K.K. (Tokyo, Japan), which we also thank for the gift of losartan and hydrochlorothiazide used in this study.

1 Rosamond W, Flegal K, Friday G, Furie K, Go A, Greenlund K, Haase N, Ho M, Howard V, Kissela B, Kittner S, Lloyd-Jones D, McDermott M, Meigs J, Moy C, Nichol G, O'Donnell CJ, Roger V, Rumsfeld J, Sorlie P, Steinberger J, Thom T, Wasserthiel-Smoller S, Hong Y. Heart disease and stroke statistics-2007 update: a report from the American Heart Association Statistics Committee and Stroke Statistics Subcommittee. Circulation 2007; 115: e69-e171.

2 Thom T, Haase N, Rosamond W, Howard VJ, Rumsfeld J, Manolio T, Zheng ZJ, Flegal K, O'Donnell C, Kittner S, Lloyd-Jones D, Goff Jr DC, Hong Y, Adams R, Friday G, Furie K, Gorelick P, Kissela B, Marler J, Meigs J, Roger V, Sidney S, Sorlie P, Steinberger J, Wasserthiel-Smoller S, Wilson M, Wolf P. Heart disease and stroke statistics-2006 update: a report from the American Heart Association Statistics Committee and Stroke Statistics Subcommittee. Circulation 2006; 113: e85-e151.

3 Timmermans PB, Carini DJ, Chiu AT, Duncia JV, Price Jr WA, Wells GJ, Wong PC, Wexler RR, Johnson AL. Angiotensin II receptor antagonists. From discovery to antihypertensive drugs. Hypertension 1991; 18: III136-III142.

4 Carr AA, Prisant LM. Losartan: first of a new class of angiotensin antagonists for the management of hypertension. J Clin Pharmacol 1996; 36: 3-12.

5 Goldberg AI, Dunlay MC, Sweet CS. Safety and tolerability of losartan potassium, an angiotensin II receptor antagonist, compared with hydrochlorothiazide, atenolol, felodipine ER, and angiotensin-converting enzyme inhibitors for the treatment of systemic hypertension. Am J Cardiol 1995; 75: 793-795.

6 Weir MR, Elkins M, Liss C, Vrecenak AJ, Barr E, Edelman JM. Efficacy, tolerability, and quality of life of losartan, alone or with hydrochlorothiazide, versus nifedipine GITS in patients with essential hypertension. Clin Ther 1996; 18: 411-428.

7 Oparil S, Barr E, Elkins M, Liss C, Vrecenak A, Edelman J. Efficacy, tolerability, and effects on quality of life of losartan, alone or with hydrochlorothiazide, versus amlodipine, alone or with hydrochlorothiazide, in patients with essential hypertension. Clin Ther 1996; 18: 608-625.

8 Lacourciere Y, Brunner H, Irwin R, Karlberg BE, Ramsay LE, Snavely DB, Dobbins TW, Faison EP, Nelson EB. Effects of modulators of the renin-angiotensin-aldosterone system on cough. Losartan Cough Study Group. J Hypertens 1994; 12: 1387-1393.

9 Brenner BM, Cooper ME, de Zeeuw D, Keane WF, Mitch WE, Parving HH, Remuzzi G, Snapinn SM, Zhang Z, Shahinfar S. Effects of losartan on renal and cardiovascular outcomes in patients with type 2 diabetes and nephropathy. N Eng/ J Med 2001; 345: 861-869.

10 Dahlof B, Devereux RB, Kjeldsen SE, Julius S, Beevers G, de Faire U, Fyhrquist F, Ibsen H, Kristiansson K, Lederballe-Pedersen O, Lindholm LH, Nieminen MS, Omvik P, Oparil S, Wedel H. Cardiovascular morbidity and mortality in the Losartan Intervention For Endpoint reduction in hypertension study (LIFE): a randomised trial against atenolol. Lancet 2002; 359: 995-1003.

11 Dahlof B, Lindholm LH, Hansson L, Schersten B, Ekbom T, Wester PO. Morbidity and mortality in the Swedish Trial in Old Patients with Hypertension (STOP-Hypertension). Lancet 1991; 338: 1281-1285.

12 ALLHAT Officers and Coordinators for the ALLHAT Collaborative Research Group. Major outcomes in high-risk hypertensive patients randomized to angiotensin-converting enzyme inhibitor or calcium channel blocker vs diuretic: The Antihypertensive and Lipid-Lowering Treatment to Prevent Heart Attack Trial (ALLHAT). Jama 2002; 288: 2981-2997.

13 Chobanian AV, Bakris GL, Black HR, Cushman WC, Green LA, Izzo Jr JL, Jones DW, Materson BJ, Oparil S, Wright Jr JT, Roccella EJ. The Seventh Report of the Joint National Committee on Prevention, Detection, Evaluation, and Treatment of High Blood Pressure: the JNC 7 report. Jama 2003; 289: 2560-2572.

14 Ogihara T, Kikuchi K, Matsuoka H, Fujita T, Higaki J, Horiuchi M, Imai Y, Imaizumi T, Ito S, Iwao H, Kario K, Kawano Y, Kim-Mitsuyama S, Kimura G, Matsubara H, Matsuura H, Naruse M, Saito I, Shimada K, Shimamoto K, Suzuki H, Takishita S, Tanahashi N, Tsuchihashi T, Uchiyama M, Ueda S, Ueshima H, Umemura S, Ishimitsu T, Rakugi H. The Japanese Society of Hypertension Guidelines for the Management of Hypertension (JSH 2009). Hypertens Res 2009; 32: 3-107.

15 McCurley JM, Hanlon SU, Wei SK, Wedam EF, Michalski M, Haigney MC. Furosemide and the progression of left ventricular dysfunction in experimental heart failure. J Am Coll Cardiol 2004; 44: 1301-1307.

16 Saruta T, Ogihara T, Matsuoka H, Suzuki H, Toki M, Hirayama Y, Nonaka K, Takahashi K. Antihypertensive efficacy and safety of fixed-dose combination therapy with losartan plus hydrochlorothiazide in Japanese patients with essential hypertension. Hypertens Res 2007; 30: 729-739.

17 Groholm T, Finckenberg P, Palojoki E, Saraste A, Backlund T, Eriksson A, Laine M, Mervaala $E$, Tikkanen I. Cardioprotective effects of vasopeptidase inhibition vs angiotensin type 1-receptor blockade in spontaneously hypertensive rats on a high salt diet. Hypertens Res 2004; 27: 609-618.

18 Zhou MS, Schulman IH, Jaimes EA, Raij L. Thiazide diuretics, endothelial function, and vascular oxidative stress. J Hypertens 2008; 26: 494-500. 
19 Hayashi K, Kimata H, Obata K, Matsushita A, Fukata A, Hashimoto K, Noda A, Iwase $M$, Koike $Y$, Yokota M, Nagata $K$. Xanthine oxidase inhibition improves left ventricular dysfunction in dilated cardiomyopathic hamsters. J Card Fail 2008; 14: 238-244.

20 Kato MF, Shibata R, Obata K, Miyachi M, Yazawa H, Tsuboi K, Yamada T, Nishizawa T, Noda A, Cheng XW, Murate T, Koike Y, Murohara T, Yokota M, Nagata K. Pioglitazone attenuates cardiac hypertrophy in rats with salt-sensitive hypertension: role of activation of AMP-activated protein kinase and inhibition of Akt. J Hypertens 2008; 26: 1669-1676.

21 Nagata K, Iwase M, Sobue T, Yokota M. Differential effects of dobutamine and a phosphodiesterase inhibitor on early diastolic filling in patients with congestive heart failure. J Am Coll Cardiol 1995; 25: 295-304.

22 Nagata K, Somura F, Obata K, Odashima M, Izawa H, Ichihara S, Nagasaka T, Iwase M, Yamada Y, Nakashima N, Yokota M. AT1 receptor blockade reduces cardiac calcineurin activity in hypertensive rats. Hypertension 2002; 40: 168-174.

23 Somura F, Izawa H, Iwase M, Takeichi Y, Ishiki R, Nishizawa T, Noda A, Nagata K, Yamada Y, Yokota M. Reduced myocardial sarcoplasmic reticulum $\mathrm{Ca}(2+)$-ATPase mRNA expression and biphasic force-frequency relations in patients with hypertrophic cardiomyopathy. Circulation 2001; 104: 658-663.

24 Sakata Y, Yamamoto K, Mano T, Nishikawa N, Yoshida J, Hori M, Miwa T, Masuyama T. Activation of matrix metalloproteinases precedes left ventricular remodeling in hypertensive heart failure rats: its inhibition as a primary effect of Angiotensin-converting enzyme inhibitor. Circulation 2004; 109: 2143-2149.

25 Nagata K, Obata K, Xu J, Ichihara S, Noda A, Kimata H, Kato T, Izawa H, Murohara T, Yokota M. Mineralocorticoid receptor antagonism attenuates cardiac hypertrophy and failure in low-aldosterone hypertensive rats. Hypertension 2006; 47: 656-664.

26 Wang CT, Navar LG, Mitchell KD. Proximal tubular fluid angiotensin II levels in angiotensin II-induced hypertensive rats. J Hypertens 2003; 21: 353-360.

27 Mitchell KD, Bagatell SJ, Miller CS, Mouton CR, Seth DM, Mullins JJ. Genetic clamping of renin gene expression induces hypertension and elevation of intrarenal Ang II levels of graded severity in Cyp1a1-Ren2 transgenic rats. J Renin Angiotensin Aldosterone Syst 2006; 7: 74-86.

28 Ueyama J, Kitaichi K, Nadai M, Iwase M, Tomyo N, Kanazawa H, Suzuki R, Takagi K, Takagi K, Hasegawa T. Effect of pioglitazone on endotoxin-induced decreases in hepatic drug-metabolizing enzyme activity and expression of CYP3A2 and CYP2C11. Eur J Pharmacol 2004; 498: 257-265.

29 Burnier M. Angiotensin II type 1 receptor blockers. Circulation 2001; 103: 904-912.

30 Ellison DH, Loffing J. Thiazide effects and adverse effects: insights from molecular genetics. Hypertension 2009; 54: 196-202.

31 Chrysant SG, Weber MA, Wang AC, Hinman DJ. Evaluation of antihypertensive therapy with the combination of olmesartan medoxomil and hydrochlorothiazide. Am J Hypertens 2004; 17: 252-259.
32 Carey RM, Wang ZQ, Siragy HM. Update: role of the angiotensin type-2 (AT(2)) receptor in blood pressure regulation. Curr Hypertens Rep 2000; 2: 198-201.

33 Barber MN, Sampey DB, Widdop RE. AT(2) receptor stimulation enhances antihypertensive effect of AT(1) receptor antagonist in hypertensive rats. Hypertension 1999; 34: 1112-1116.

34 Pickkers P, Hughes AD, Russel FG, Thien T, Smits P. Thiazide-induced vasodilation in humans is mediated by potassium channel activation. Hypertension 1998; 32: 1071-1076.

35 Pickkers P, Garcha RS, Schachter M, Smits P, Hughes AD. Inhibition of carbonic anhydrase accounts for the direct vascular effects of hydrochlorothiazide. Hypertension 1999; 33: 1043-1048.

36 Gamba G, Miyanoshita A, Lombardi M, Lytton J, Lee WS, Hediger MA, Hebert SC. Molecular cloning, primary structure, and characterization of two members of the mammalian electroneutral sodium-(potassium)-chloride cotransporter family expressed in kidney. J Biol Chem 1994; 269: 17713-17722.

37 Sugden PH, Clerk A. Cellular mechanisms of cardiac hypertrophy. J Mol Med 1998; 76: 725-746.

38 Brunner HR. Experimental and clinical evidence that angiotensin II is an independent risk factor for cardiovascular disease. Am J Cardiol 2001; 87: 3C-9C.

39 Suzuki J, Matsubara H, Urakami M, Inada M. Rat angiotensin II (type 1A) receptor mRNA regulation and subtype expression in myocardial growth and hypertrophy. Circ Res 1993; 73: 439-447.

40 Bader M, Ganten D. Update on tissue renin-angiotensin systems. J Mol Med 2008; 86: 615-621.

41 Iwanami J, Mogi M, Iwai M, Horiuchi M. Inhibition of the renin-angiotensin system and target organ protection. Hypertens Res 2009; 32: 229-237.

42 Kobori H, Nangaku M, Navar LG, Nishiyama A. The intrarenal renin-angiotensin system: from physiology to the pathobiology of hypertension and kidney disease. Pharmacol Rev 2007; 59: 251-287.

43 Uzu T, Harada T, Namba T, Yamamoto R, Takahara K, Yamauchi A, Kimura G. Thiazide diuretics enhance nocturnal blood pressure fall and reduce proteinuria in immunoglobulin A nephropathy treated with angiotensin II modulators. J Hypertens 2005; 23: 861-865.

44 Zhou X, Matavelli LC, Ono H, Frohlich ED. Superiority of combination of thiazide with angiotensin-converting enzyme inhibitor or AT1-receptor blocker over thiazide alone on renoprotection in L-NAME/SHR. Am J Physiol Renal Physiol 2005; 289: F871-F879.

45 Kurtz TW, Griffin KA, Bidani AK, Davisson RL, Hall JE. Recommendations for blood pressure measurement in humans and experimental animals. Part 2: Blood pressure measurement in experimental animals: a statement for professionals from the subcommittee of professional and public education of the American Heart Association council on high blood pressure research. Hypertension 2005; 45: 299-310. 